\title{
ANALYSIS OF MINISTRY OF DEFENCE OF UKRAINE CRISIS COMMUNICATIONS WITHIN THE RUSSIAN FEDERATION INFORMATION AGGRESSION AGAINST UKRAINE IN 2016-2018
}

Keywords: crisis communications, crisis management, information policy, security and defence sector, destructive information campaigns.

ABSTRACT: The active phase of hybrid aggression of the Russian Federation which was started from the illegal annexation of Crimea and occupation of the several regions of Donetsk and Luhansk oblasts in 2014 has been accompanied by massive information and disinformation campaigns against Ukraine launched by the aggressor. They were accompanied by spreading fakes, deepfakes, propaganda messages, and manipulations.

The crisis communications, including efficient information environment monitoring, are important for stable development of any structure and organization.

Hybrid component of the conflict was observable since the inception. Information and psychological warfare, humiliation of Ukrainian language and culture, falsification of the Ukrainian history, and establishment of alternative reality of the distorted information picture of the world by the Russian media were identified as one of the most relevant threats to the national security of Ukraine. The aggressor spreads and tells own narratives. Current challenges and threats to the national security of Ukraine determine the overall necessity of finding a viable, appropriate,

1 Candidate of Sciences (Public Administration), Doctoral Student at the Educational and Research Centre for Strategic Communications in the Sphere of National Security and Defence, National Defence University of Ukraine named after Ivan Cherniakhovskyi,mou-infopress@ukr.net. ORCID: 0000-0002-0805-4092

2 Chief of Training Section, Educational and Research Centre for Strategic Communications in the Sphere of National Security and Defence, National Defence University of Ukraine named after Ivan Cherniakhovskyi, perevod_vu@ukr.net. ORCID: 00000002-2614-7014. 
effective, as well as integrated tool, which will make possible to establish consistent cooperation in the security and defence sector.

Qualitative analysis of the organization of work of elements and units of the Ministry of Defence of Ukraine during the armed aggression of the Russian Federation against Ukraine in order to develop new effective mechanisms of countering the aggression is of upmost importance.

The development of this work on the basis of the unique experience will give the chance to establish effective resistance to destructive information campaigns, crisis situations which are conducted by the external aggressor. Purpose of the article is a detailed analysis of the gradual development of mechanisms of implementation of state information policy by the Ministry of Defence of Ukraine while countering hybrid aggression in 2014-2019, as well as development of further recommendations for reform of the abovementioned direction.

\section{INTRODUCTION}

The article is devoted to the analysis of the mechanism of crisis communications management within the Armed Forces of Ukraine considering the experience of crisis communications localization in the process of fighting against and deterring the Russian Federation armed aggression against Ukraine. Thus, we have analyzed the current crisis communications experience and synthesized proposals for further activities.

Our research covers the crisis communications articles and legal documents, as well as own experience in crisis management related to activities in the Ministry of Defence of Ukraine.

The research has revealed that since the launch of the Russian Federation armed aggression against Ukraine the state system of communications was not ready for new challenges and threats and needed new managerial solutions.

In order to increase effectiveness of communications system there was developed the system of strategic communications and legal documents, established the section of coordination of strategic communications and monitoring, Educational and Research Centre for Strategic Communications in the sphere of national security and defence within the Ministry of Defence of Ukraine. The Ukrainian Ministry of Defence strategic communications experts have a unique crisis management experience gained 
during the past years of the Russian Federation armed aggression against Ukraine.

We have stated that in order to localize the crisis situations in case of emergencies and consequences management in 2017 the Ministry of Defence of Ukraine was proposed to implement the "Instruction on Crisis Communications Organization". The analysis of the document shows that while localizing crises it is necessary to develop the crisis response plan. Moreover, for immediate public informing on the event, during an hour after the crisis announcement, it is necessary to form the crisis response group consisting of responsible strategic communications officials depending on crisis specifics. If necessary, in accordance with this plan the group travels to the crisis region.

The conclusions include proposals on organization of the crisis response mechanism organization to be considered in theory and practice.

\section{ANALYSIS OF RECENT RESEARCH AND PUBLICATIONS THAT HAVE BEGUN TO ADDRESS THIS ISSUE}

A significant contribution to the development of theoretical and practical substantiation of the mechanisms of using crisis communications was the research of Ukrainian scientists V.A. Lipkan, D.V. Dubov, V.V. Petrov, Y.I. Radkovets, O. F. Salnikova, S.I. Antonenko, A.V. Barovska, T. M. Bezverkhnyuk, O.L. Valevsky, O.V. Voitko, and others. However, the relevance and issues of the topic of the material require further research in this area.

\section{FORMULATION OF THE GOALS OF THE ARTICLE (TASK STATEMENT)}

In this article, the authors aim to analyze the experience in organizing a system of work in crisis communication direction, in the context of experience in developing a system of strategic communications in the security and defence sector of Ukraine. 


\section{PRESENTING MAIN MATERIAL}

The Strategic Communications Concept of the Ministry of Defence of Ukraine and Armed Forces of Ukraine No. 612 dd 22 November, 2017 defines one of the key problems to be resolved - proper crisis communications, strategic communications, and strategic planning training. (Concept, 2017).

Every crisis situation affects the Ukrainian Armed Forces activities; even sometimes endanger the tasks execution. Considering this fact the military leaders and officials should realize the nature, characteristics, basic phases of crisis, as well as know features of crisis communications. Any crisis situation is rapidly spread through information environment and becomes well-known, it is necessary to respond appropriately to crisis challenges and be prepared in advance.

The crisis communications organization means the establishment of communications system such as the sequence of actions generally reflecting the implementation and existence of the effective crisis communications system, as well as its deployment plan in case of crisis. (Basic strategic communications in national security and defence. Handbook, 2020, p. 40).

Any crisis is always unexpected event which can negatively affect health and security, reputation, image and financial life. Since the very beginning of the crisis it is highly important to outline its nature, avoid panic and act in order to manage the crisis. Scientists define different crises such as financial, man-made, social, managerial, force majeure, and information ones which are the most popular nowadays. In any situation, it is very important to establish 24/7 monitoring of information in the media and social networks, it is necessary to monitor constantly the situation, analyze the sources that disseminate information, understand their reliability, credibility, and influence. The main goal is to provide an effective solution to the crisis situation and minimize the negative consequences and solve the following tasks: neutralize criticism, provide urgent information, promptly monitor events, try to predict future events, act ahead, and direct situation in direction which is more favourable for ministry, department, company or organization. 
The biggest problem in any crisis is to ensure immediate response and accumulate efforts of all interested persons for efficient work avoiding emotional influence and panic. Ms Natalya Olbert-Sinko, co-founder of the public initiative "Ukrainian Crisis Media Centre", formulated 11 crisis response rules. Firstly, it is necessary to be always proactive, secondly, it is necessary to communicate constantly as communication is a two-way road, it is necessary to monitor response to your messages and depending on it involve additional crisis management tools, thirdly, it is necessary to ensure immediate response, particularly during the first four crisis hours; define immediately speakers, prepare, publications, press releases, statements, organize work at the scene, as interested journalists will report at the scene, ensure the appropriate internal communications in order all persons involved understand the problem nature and main communications messages. Fourthly, it is necessary to ensure permanent monitoring in media and social media. Social media are perfect technologies for monitoring of the public opinion, evaluations, and views. The monitoring should reveal who spreads the information; exaggerate the problem depending on posts influence. Fifthly, while working on social media, while communicating with journalists it is very important to take all measures in order to limit speculations and rumours. Sixthly, if the crisis results in serious consequences related to death and health damage, it is important to express condolences to victims, families and words of encouragement. The comments should be directed to informing audiences on prospects in order to reduce their focus on the problem. It is necessary to tell about what was done to manage the crisis and about future plans. Seventhly, all comments should be based on true information. Seventhly, the communication should involve experienced speakers, experts, and leaders as it is better when an emotional, interesting, and open-minded person brief on situation. Ninthly, the success will be in flexibility and adaptability, avoidance of categoricity, ability to reassure, and avoidance of conflicts. Tenthly, it is necessary to use social media in information spreading during the crisis. And the eleventh rule means active internal communications and credibility within any organization which will contribute to successful crisis management. (11 rules of crisis management, 2016). 
Media expert Oleksiy Kharchenko stresses that in crisis even experienced specialists make errors because of lack of time. Thus, the planning documents should include the statement on errors prevention:

- avoid situations when journalists feel any concealment as in this case they are motivated to conduct journalist investigation;

- publish and post your information about crisis in order to avoid response to false information; and

- avoid the following myths such as "information will result in panic"; "crisis communications could be managed instinctively", "it is impossible to be ready for crisis as every particular crisis is unique", "we will tell journalist how to report on the situation". (Kosar L., 2018, p. 70).

The strategic communications experts of the Ministry of Defence of Ukraine have unique crisis management experience gained during the years of the Russian federation armed aggression.

According to the draft of the strategic communications doctrine, the crisis results from an event about which the media inform the population. (Draft of Strategic Communications Doctrine of the Armed Forces of Ukraine, 2020, pp. 26-27). Sometimes, the mass media are the source of the crisis development. Cooperation of the state institutions with the society and the mass media during crises is characterized as "crisis communications". The crisis communications include the sequence of actions in order to provide immediate and sequential development and functioning of effective system of crisis communications, as well as crisis response plan.

The crisis communications are principally aimed at protecting crisis participants' image and reputation, event sometimes for their future existence. The majority of possible physical crises are known to military leaders; management scenarios are described and included in appropriate plans. The readiness to implement these plans is organic to the military structure. Every information crisis is not organic and negatively influences the activities of troops (forces) and sometimes affects the fulfilment of tasks assigned. One of the main strategic communications system tasks is crisis communications. Usually, crisis communications consist of three phases such as crisis preparation, crisis response, and consequences management. Their sequence and tasks depend on scale, social importance, and characteristics of target audiences involved, preparation time limit etc. 
Typical problems of crisis communications are the reduction of controlled sources which spread reliable information, lack of clear and understandable interpretation of events, loss of confidence in official communication channels, disruption of information flows, their inability to perform normal functions, and creating situational information circulation systems (social media, popular messengers and others).

Since the crisis creates non-standard conditions, complicates the rational understanding of the situation and the choice of adequate strategy, communication with the public should be based on prompt dissemination of messages that meet the expectations and needs of the target audiences, taking into account the specific situation and professional behaviour of the media.

The first 24 hours after the crisis are considered crucial. During this period, it is necessary to provide the media with information about the event and its causes, explain the position and vision of the situation, and inform the public about the measures taken to minimize the effects of the crisis.

The below described procedure for organizing crisis communications within the Ministry of Defence of Ukraine was proposed in 2017 in accordance with the "Instruction on the organization of crisis communications".

The instruction provided the algorithm of personnel actions, which is part of the crisis response system within the strategic communications. In case of emergencies, large-scale events, situations which can cause public outcry, it is important to inform the appropriate persons in the Ministry of Defence and General Staff, including press secretary, in order to respond effectively to them in the information space.

According to it, during one hour after crisis it is necessary to inform the responsible officials on it, it is necessary to form the crisis response group in order to inform the public.

Then, during one hour after formation of the crisis response group, it is necessary to form the briefing group consisting of speakers, Ministry of Defence journalists, and cameramen. The group personnel vary depending on tasks specifics.

The crisis response group is responsible for ensuring permanent briefing of the public and media by providing comments, posting information 
on official websites and disseminating it on social networks, and coordinating the work of the briefing group. Responsible persons provide information on the state of affairs to the crisis response group every hour, and in the event of a sharp change in the situation, provide it immediately.

The briefing group work near the crisis region. Moreover, it is responsible for cooperation with civil media at the scene, timely reporting on the crisis by commenting and providing photo and video at the scene.

Commanders and chiefs in whose area of responsibility the crisis unfolds facilitate the work of the media, even if the crisis involves civil services and authorities.

The first comment on crisis should be provided by the responsible person during an hour after the crisis announcement and report to the duty office of the Ministry of Defence of Ukraine.

The information on wounded in action and killed in action personnel (including full names and personal data) will be disclosed as soon as possible considering the restrictions of current legislation and only after the responsible commander deputy or any other responsible person acknowledges that close relatives and family members are informed on the death of this military.

The accident or incident should be covered in the form of a single disclosure of information (one message), and when preparing information about the event, it is important to consider the following details such as place and time of the accident or incident, full names and details of dead or injured in the publication until their close family members are officially notified on.

\section{CONCLUSIONS}

Considering the variety of current challenges and threats, it is impossible to foresee which crisis can take place and when, but it is necessary to prepare to it in advance. The crisis management mechanism should be developed and worked out in theory and practice, such as it is necessary to

- prepare the actions algorithm in case of crisis; 
- have a professional team of specialists which have practical experience in crisis management and are ready to act in crisis;

- be immediately informed on crisis and develop and work out the effective crisis situations warning system;

- convene (sometimes during an hour) the crisis response group and prepare the crisis response plan considering the situation specifics;

- agree immediately the action plan with direct leaders, as well as involve them to provide comments, if necessary;

- if necessary, form the immediate response group on informing at the scene in order to ensure the cooperation and work with journalists and local population;

- develop the system of immediate informing of all specialists involved in crisis response actions and events;

- ensure opportune informing through mass media;

- in case of a protracted crisis, ensure systematic updating of information through departmental sources of information (sites, social networks, and radio) and through the media;

- find time for after-action review process and timely actions corrections; and

- upon completion of actions of the crisis management, be sure to conduct a detailed analysis and make changes to the algorithm of actions in case of negative response to it.

\section{BIBLIOGRAPHY:}

Kontseptsiia stratehichnykh komunikatsii Ministerstva oborony Ukrainy ta Zbroinykh Syl Ukrainy: zatv. nakazom Ministerstva oborony Ukrainy vid 22.11.2017 № 612 [Concept of Strategic Communications of the Ministry of Defence of Ukraine and Armed Forces of Ukraine approved by the Ministry of Defence of Ukraine order dd 22.11.2017, No. 612 [Online resource]. Downloaded from: http://www.mil.gov.ua/ content/mou_orders/612_nm_2017.pdf.

Group of authors. (2020) Osnovy stratehichnykh komunikatsii u sferi zabezpechennia natsionalnoi bezpeky ta oborony. Navchalnyi posibnyk [Basic strategic communications in national security and defence. Handbook]. Kyiv: National Defence University of Ukraine named after ivan Cherniakhovskyi. 
Kosar L. and others. (2018) Komunikatsiinyi instrumentarii dlia derzhavnykh sluzhbovtsiv [Communications tools for state servants], Kyiv: Ministry of Information Policy11 pravil antikrizisnyh kommunikacij. (2016) [11 rules of crisis management]. [Online resource]. Downloaded from: https://dengi.ua/article/amp?id=1786198.

Proiekt doktryny zi stratehichnykh komunikatsii Zbroinykh Syl Ukrainy, 2020 [Draft of Strategic Communications Doctrine of the Armed Forces of Ukraine, 2020]. pp. 26-27. 